\title{
THE IMPACT OF JAMKESMAS ON HEALTHCARE UTILIZATION IN EASTERN REGIONS OF INDONESIA: A PROPENSITY SCORE MATCHING METHOD
}

\author{
Novat Pugo Sambodo \\ Erasmus School of Health Policy and Management, Erasmus Universiteit Rotterdam \\ Research Associate Pusat Kebijakan Pembiayaan dan Manajemen Asuransi Kesehatan, \\ Medical Faculty Universitas Gadjah Mada \\ Jl. Farmako, Sekip Utara, Yogyakarta 55281
}

Correspondence E-mail: pugosambodo@gmail.com

Received: September 2018; Accepted: October 2018

\begin{abstract}
Underutilization of health care for the poor is one critical problem in Indonesia. Out of pocket share is dominant on overall health financing. Therefore, it is plausible that low demand of modern healthcare services mainly relates to financial aspect. In 2008, the government of Indonesia has introduced health insurance schemes for the poor to help them overcome the problem of medical costs barrier called Jamkesmas (Social Health Insurance). This paper examines the impact evaluation of Jamkesmas to health care utilization in Eastern Indonesia. Data are drawn from Indonesia Family Life Survey East (IFLS-East) that held in 2012. This data only covers the eastern regions of Indonesia that widely known has relatively lower performance in development and infrastructure. Moreover, this study employs Propensity Score Matching (PSM) approach to analyse the data. The results show that average treatment effect for treated group are positive for outpatient utilization. In addition, availability of the healthcare facility variables, travelling time and distance to district capital are factors that determine Jamkemas coverage in Eastern Indonesia.
\end{abstract}

Keywords: social health insurance, healthcare utilization, impact evaluation JEL Classification: I13, I15, H43

\section{INTRODUCTION}

Underutilization of health care for the poor is one critical problem in Indonesia. According to Somanathan (2008), out of pocket share during 1995 to 2004 was between $60-70 \%$ on overall health financing. Therefore, it is plausible that low demand of modern healthcare services mainly relates to financial aspect (Somanathan 2008, p. 1). Hence, Government of Indonesia (GoI) tries to reform social safety nets in order to protect the most vulnerable family in the hardship situation, i.e. economics crises in 1997 and 2008. GoI has introduced various health insurance schemes for the poor to help them overcome the problem of medical costs barrier.

Health insurance in Indonesia had been gone through several evolutions. It started with
Dana Sehat in 1969, Jaminan Pemeliharaan Kesehatan Masyarakat (JPKM) in 1992, and Health Card in 1994. After that, it was followed by Social Safety Nets or Jaring Pengaman Sosial (JPS) which was introduced to mitigate the impact of Asian Financial Crisis in 1997-1998. Then, the GoI initiated Asuransi Kesehatan Untuk Masyarakat Miskin (Askeskin) in 2005-2007, and finally it is replaced by Jaminan Kesehatan Masyarakat (Jamkesmas) ${ }^{1}$ in 2008 (Vidyatama et al. 2014). Jamkesmas is a social assistance for healthcare that is provided for the poor and those who cannot afford the healthcare fee. GoI has allocated around 500 million USD or around $20 \%$ of all social assistance budget to funding Jamkesmas program. In addition,

\footnotetext{
${ }^{1}$ To avoid any confusion, there is also JAMKESDA which is a similar insurance but the regulation and coverage are under district or city local government responsibility.
} 
Ministry of Health appointed to implement this program starting from 2008 until early 2014. Currently, BPJS (Social Security Agency) program substitutes Jamkesmas with broader coverage, i.e. not only for the poor. However, the lesson from Jamkesmas implementation remains relevant and valuable for policy analysis.

There have been many studies evaluating health insurance program in Indonesia. The latest study by Vidyatama et al. (2014) finds that health insurance owner $8 \%$ more likely using healthcare service when falling sick and it becomes $5 \%$ if people who are not sick are included in the estimation. Other study tries to contrast the effect of Askeskin and non-Askeskin (Aji et al. 2013). Their research finding supports the argument of financial barrier; both types of health insurance program can decrease out of pocket payment. Distance and location factors also have a significant influence on healthcare utilisation, especially for rural community. In contrast, people living in urban community are less sensitive to distance, but relatively more sensitive to medical fee (Erlyana et al. 2011).

In brief, contributions of this paper have three points. First, this paper gives more attention to eastern region of Indonesia than try to get national level studies. Most previous studies on the health insurance impact evaluation in Indonesia have a limitation on capturing geographical aspect and eastern Indonesia focus. Nevertheless, this region is relatively lacking in many social development indicators as compared to the western regions. Furthermore, Indonesia Statistic Office reported that $70 \%$ of underdeveloped districts are located in eastern Indonesia. It hopes give more understanding of Jamkesmas implementation than get only general idea of national level.

Second, this study also includes more variables such as travel time, distance and availability of service variables. Unlike other datasets such as SUSENAS and RISKESDAS used by Vidayatama et.al (2014), and Sparrow et.al (2013), IFLS-East has a possibility to merge between individual and household information with community or village data. IFLS-East data is the newest IFLS since the previous IFLS, IFLS 4 taken in 2007. Thus, this paper expect more update information as compared with other paper using previous IFLS data like IFLS 3 (Erlyana et al. 2011) or IFLS 1 and IFLS 2 (Hidayat et al. 2010).

This paper aims to analyse the impact of Jamkesmas on healthcare utilization in eastern part of Indonesia. With this objective, the study attempts to answer two research questions: (1) Does Jamkesmas significantly help the poor household to increase their health care utilization when falling ill? (2) Is there any difference of household choice preference between the public and the private health services given variables in the model?

The following part of this essay briefly describes Indonesian health insurance from reform from 1998 (after economic crisis) with Social Safety Net (SSN) until recent implementation of Social Security Agency (BPJS). Section 3 outlines some characteristics of data we use in this research. Empirical challenge and methodology to deal with those challenges will be discussed in section 4 . Section 5 discusses the result of this study and discussion. A final section highlights what this paper main finding and policy implication that we can make given the result from this paper.

\section{Reform in Indonesian Social Insurance}

Recently the Government of Indonesia (GoI) has set an ambition to have every citizen covered by insurance. GoI initiated Social Security Agency or Badan Penyelenggara Jaminan Sosial (BPJS) in 2014. It is a part of the implementation of National Social Security System Law 2004 no. 40 and Social Security Agency Law 2011 no. 24. The law is introduced as a response of a rigid limitation in the insurance coverage that could only reach people with formal employment status. These insurances include Aspen, Askes, Jamsostek and Asabri. Hence, the ultimate goal of BPJS is to expand the coverage and improve the service to its beneficiaries. 
Before Jamkesmas is implemented, Indonesia has a long experience in providing insurance to its citizens, see Figure 1. In 1998 Indonesia introduced Jaring Pengaman Sosial or Social Safety Net as a response of economic crisis. The intention of this program is to protect the poor from economic turbulence during this Asian Financial Crisis 1997-1998. Shrinking indicators, like a massive decline of unemployment rate, high inflation and socio-politic crisis, make the poor more vulnerable. As part of JPS, a health card program is introduced to poor households to waive the fee to access the public healthcare provider, i.e. Public Health Centre (Puskesmas) and public hospital.

In 2005 the GoI attempted to reform the social health insurance with broader beneficiaries. The government introduced Askeskin (health insurance for the poor) with the goal to expand the coverage to the informal sector workers that had not been covered by the existing insurances. Afterwards, the GoI appointed Ministry of Health to manage the financial aspect of Askeskin because there had been many requests for evaluation and improvement. Then, it was renamed to Jamkesmas in 2008. In this program, the near poor group was included as eligible recipient. Furthermore, to standardize with the establishment of National Social Assistance, the GoI incorporated Jamkemas under National Health Insurance (JKN); Jamkesmas is managed by BPJS. With this merger, all Jamkesmas's members automatically become member of National Health Insurance Program under BPJS.
According to Harimurti et.al. (2013), there are several changes in Jamkesmas compared to Askeskin. First, the insurance fee is higher, it increases between IDR 5,000 to IDR 6,500 per individual per month. Second, Jamkesmas only gives the limited basic package with some specific exclusions of benefit and no cost-sharing. However, the member may get an extended package as add-in. Another benefit of Jamkesmas is that the medicine is covered with prescribed evidence. Jamkesmas holders can exercise the insurance in Puskesmas, Public Hospital and some registered private hospital (Harimurti et.al 2013, p.14).

According to World Bank background paper (World Bank 2012), the official number of Jamkesmas recipients in 2010 approximately 74.6 million people. In term of budget, the average cost of health services utilized per card is Rp6,250, while the administrative cost itself is Rp9,362 (US\$ 0.9). Moreover, this report also shows that Jamkesmas successfully cover around $41 \%$ of poor household. To manage the implementation, Ministry of Health works together with public hospitals and local health centers as service providers and fee claims. BPJS regulates the eligibility and targeting. PT Askes handles the card production and distribution. Ministry of Finance is responsible for financing the disbursement. Local government also has a role to distribute Jamkesmas cards, provide sufficient socialization and undertake monitoring and evaluation.

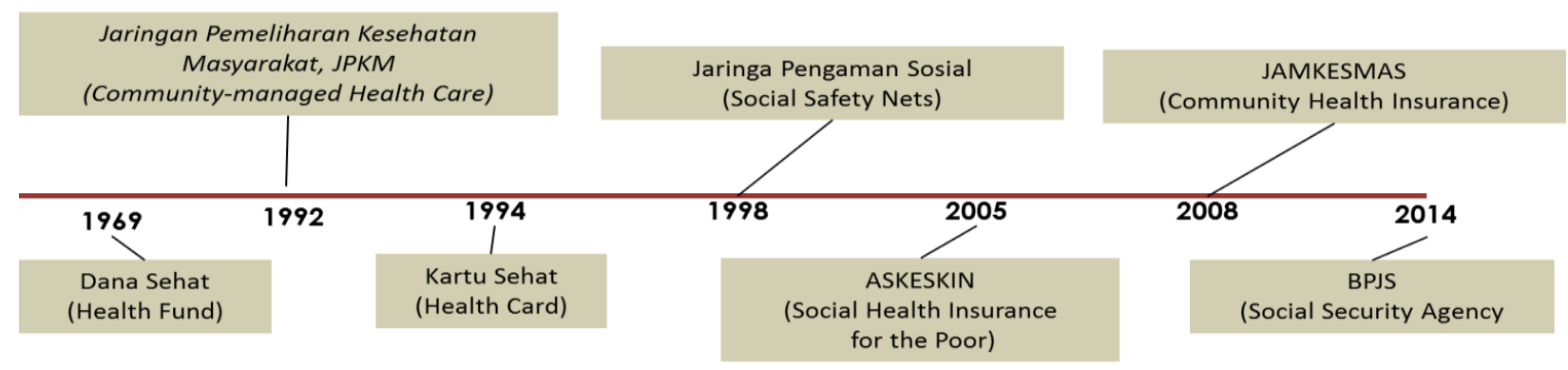

Source: Author's estimation based on Vidyatama et.al. (2014)

Figure 1. Evolution of Health Insurance in Indonesia 


\section{RESEARCH METHOD}

\section{Data}

This paper utilizes the IFLS-East 2012 (Sikoki et al. 2013), which is the first survey that specifically covers the eastern provinces of Indonesia that have never been surveyed by 4 previous IFLS. It covers the information in individual, household and community level. There are seven provinces surveyed: Kalimantan Timur, Nusa Tenggara Timur, Maluku, Maluku Utara, Papua, Papua Barat, and Sulawesi Tenggara. Moreover, IFLS-East data involves 99 villages consisting of 3,159 and 2,547 households. Within these households, 10,887 individuals are interviewed (Satriawan et al. 2014). The richness of information presented in this dataset supports the analysis, thus leading to better estimates in explaining the independent variables. IFLS-East data is accessible at this URL <http://surveymeter.org/research/3/iflseast>.

This study exercises some dependent variables, including outpatient variables for total, public health centres and private health services. This paper also tries to capture the impact of Jamkesmas on inpatient utilization. Similar to outpatient outcome, it also classifies both public and private. Using the household expenditure dataset from IFLS, this paper constructs the out of pocket variables and the catastrophic health expenditure incident if the health expenditure of the household exceeds $15 \%$ of its total.

The fundamental interest of this program evaluation study is to investigate the real impact of Jamkesmas on the main outcome. However, we face some empirical challenges in the data. First, it is required to estimate the outcomes that capture the "true" difference between the impact of Jamkesmas to the treated group and the untreated group. This cannot be done by simply estimating the outcome, like the outpatient and inpatient service utilization or health expenditure variable of people with and without Jamkesmas. That naive approach is not sufficient to capture the causal effect relationship between program and outcomes. Hence, the main challenge for this impact evaluation study is to get the counterfactual group in the data. Each household needs to get match comparison with other household with same characteristic before get the program.

Second, the allocation of Jamkesmas is based on the eligibility determined by Indonesian Ministry of Health, and certainly it is not selected randomly. Jamkesmas is only provided for the poor and the non-poor. Hence, measuring the outcome with simple Ordinary Least Square could produce a bias estimation. This is because there is also a possibility that some poor and near poor households who are eligible, but they do not receive the benefit of Jamkesmas. These eligible households have a tendency to have less utilization, even if they hold a health insurance. If the randomness of data is satisfied, we could make an estimation with other estimation model, such as randomized selection, regression discontinuity and difference-in-difference. However, since the randomness is not satisfied, the IFLS-East dataset is a cross-sectional data. Lastly, we assumed that the eligibility of Jamkesmas are observable in variables contained in IFLS-East dataset.

In this non-ideal condition, there is one method that can solve the counterfactual group problem. It is by looking the counterfactual group within dataset that has a similar or exact characteristic of the treated group, except the fact that they get the insurance. This can be done by using the exact match Propensity Score Matching (PSM).According to Rosenbaum \& Rubin (1983), propensity score which is also known as balancing score, represent the conditional probability of observation that will be given a treatment based on the definite pretreatment specification. Furthermore, the fundamental reason of PSM is the absence of experimental framework of program and allocation of program in non-random setting. Then, the difference of treatment group and control group is not only in their status in program as a receiver, but also on the other characteristics 
that might impact on the outcome. This bias can be avoided if we can get the corresponding similar households or individuals. After estimating the outcome of both groups, we then compare those outcomes. The average difference outcome of treated and untreated groups allows us to get impact of the program on beneficiaries.

PSM approach has tree steps in order to get the average impact of the treatment. First, we need to estimate the probability of households in datasets who are receiving Jamkesmas. This is based on several selected control variables, which are observable. In this step, we can utilize Logit or Probit estimation. Both estimates only have minor difference, and the selection is based on the researcher's adjustment. In this study, the Logit method is used. The next step is to limit our analysis only for households that have a range of common supports. Then, after obtaining the range of common support for each treatment group, we pair them with the untreated household having the same or the closest balancing score. Finally, in the last step we produce the average treatment effect on the treated group (ATT) by acquiring the average difference of expected outcome (outpatient, inpatient, health spending) from people with and without Jamkesmas.

Based on Jamkesmas and datasets characteristics, this research prefer to use PSM model that also used by Sparrow et al. (2013) and Pradhan et al. (2004) for Askeskin and Health Card program, respectively. As an extension of their work, this paper is to add more specific information data on the community infrastructure, travel time or distance, and availability of healthcare facility characteristic both public and private healthcare provider. The matching model using Logit estimation is shown as follow:

$$
\begin{array}{r}
\left(\operatorname{Pr}\left(Y_{i}=1\right)\right)=\left(\beta_{0}+\beta_{1 i}\left(\alpha_{i n d}\right)+\beta_{2 i}\left(\alpha_{h h}\right)+\right. \\
\beta_{3 i}\left(\alpha_{\text {fas }}\right)+\beta_{4 i}\left(\alpha_{\text {comm }}\right)+\beta_{5 i}\left(\alpha_{\text {dist }}\right)+
\end{array}
$$$$
\left.\left.\varepsilon_{i}\right)\right)
$$

Equation (1) is the matching model, where $Y_{i}$ is an outcome of household probability that is covered by Jamkesmas $\left(\operatorname{Pr}\left(Y_{i}=1\right)\right)$ i.e $Y=1$ if yes and $Y=0$ if no.

In this logit estimation (equation 1) there are some variables that are included in the control variables. The variables in the category $a_{i n d}$ represent factors attached to person in demographic categories such as age, sex, years of education, education level, marital status, while the category $a_{h h}$ represents the household level characteristics, such as education of household head, whether of household head is female and household expenditure (food, non-food and medical expenditure). Variables in the category $\mathrm{a}_{\mathrm{fas}}$ include the availability of the supply sides, such as the availability of health center facilities, tools availability and number of staff. The category $\mathrm{a}_{\text {comm }}$ comprises of community characteristics, such as geographical and infrastructure variables. This research also gives more attention in this aspect as the sample relatively lacks in infrastructure. Furthermore, self-reported illness is not included in these covariates. It is because the inclusion of self-reported illness could lead us to a selection bias because the probability for people who are sick and actively looking for Jamkesmas is relatively high. This is also related that rich people has more tendency to report their illness rather than the poor.

This research employs the five nearestneighbours matching approach to match the treated group with the control group. The matching is based on the propensity score. After this process, the difference between those two groups is possible to calculate. To estimate the average impact of a treatment for a household that get Jamkesmas in notation $\beta p s m$, we determine the disparity between the expected outcome of the treatment group and the expected outcome of the non-treated group as mentioned earlier. In mathematical notation, this can be expressed as follow (see Sparrow et.al 2013):

$$
\beta p s m=E(y i A=1, \mathrm{~S}=1)-E(\text { WiyiA=0, } \mathrm{S}=1)
$$

In equation (2), $(y i A=1, S=1)$ is the expected outcome of household groups who receive 
Jamkesmas $(\mathrm{A}=1)$ and having a common support $(\mathrm{S}=1)$ as conditional requirement. Then, $E$ (WiyiA=0, =1) shows the potential outcome of 'artificial' control groups based on the propensity score that do not have Jamkesmas $(\mathrm{A}=0)$ and have common support $(S=1)$. We denote the weight estimated balancing score.

\section{RESULT AND DISCUSSION}

\section{Jamkesmas Coverage}

Table 3 shows the experiment result of Jamkesmas coverage that has been classified into rural and urban groups, quartiles as well as gender. It is to be noted that this table is in individual level. Even though the allocation might not be entirely received by the targeted groups, quartile 1 and quartile 2 still have the highest percentage of people holding the insur- ance, i.e. $52.61 \%$ and $43.21 \%$, respectively. This pattern indicates that Jamkesmas has reached the target that is the poor and the near poor group. However, there is an indication that Jamkesmas is utilized by unintended groups, i.e. quartile 3 and quartile 4 . This means that there is leakage of Jamkesmas allocation in eastern region of Indonesia. This finding is similar with a study done by Sparrow et al. (2013) and Vidyatama et.al (2014) in the national level case. In addition, more people in the rural area take the benefit of Jamkesmas rather than the urban counterparts. Around $44.71 \%$ of people in the rural area who receive Jamkesmas, while only $22.86 \%$ of urban people who receive Jamkesmas. Another finding is that there is no significant difference of allocation for male or female groups. They are equally likely to receive Jamkesmas.
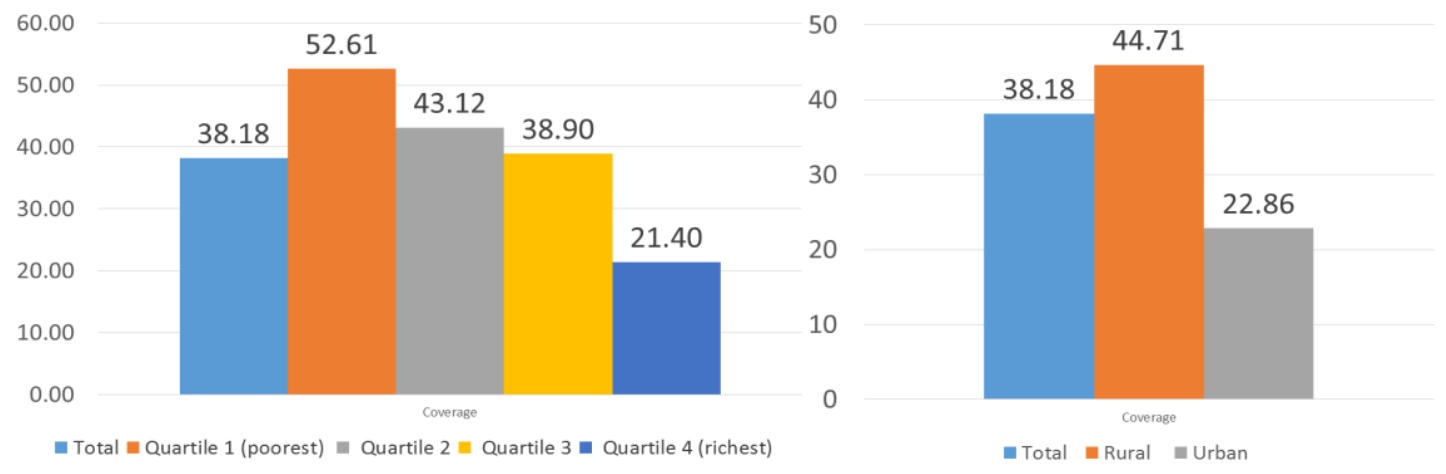

Source: Author's calculation based on IFLS-East 2012

Figure 2. Targeting of Jamkesmas Coverage in 2012

Table 1. Utilization and Health Spending for Household with or without Jamkesmas Holder

\begin{tabular}{lccc}
\hline & $\begin{array}{c}\text { Household with no } \\
\text { Jamkesmas holder }\end{array}$ & $\begin{array}{c}\text { Household with } \\
\text { Jamkesmas holder }\end{array}$ & Total \\
\hline Outpatient & 0.163 & 0.176 & 0.168 \\
Public & 0.086 & 0.122 & 0.101 \\
Private & 0.068 & 0.050 & 0.061 \\
Inpatient & 0.044 & 0.035 & 0.040 \\
$\quad$ Public & 0.037 & 0.034 & 0.036 \\
$\quad$ Private & 0.015 & 0.007 & 0.012 \\
Out of pocket health expenditure (\%) & 1.539 & 0.861 & 1.267 \\
Catastrophic health spending (more & 0.020 & 0.007 & 0.015 \\
than 15\% of total expenditure) (\%) & & & \\
\hline
\end{tabular}

Source: Author's estimation based on IFLS-East 2012 
Table 1 exhibits a naïve comparison between household with and without Jamkesmas with regards to the utilization of healthcare service, out of pocket expenditure and catastrophic health incidence. This table is based on the household level data. Jamkesmas's holder has a slightly higher average of visitation than household with no Jamkesmas. The value of 0.176 means that $17.6 \%$ of household with Jamkesmas is reported to access modern healthcare (either public or private) in the past 4 weeks. The difference gets bigger in public healthcare provider, which is 0.122 for Jamkesmas holder and only 0.086 for non- Jamkesmas household. This pattern differs from the case of outpatient private healthcare; the average number of people go to private healthcare provider is larger for non- Jamkesmas household. In terms of spending, out of pocket health expenditure for nonJamkesmas household is relatively higher, and that is almost double. Similarly, catastrophic health incidence spending is also higher for non- Jamkesmas household, though the value is very small. In general, it can be inferred that with this naïve analysis the utilization of healthcare is higher for the Jamkesmas holder and they pay less health spending.

In Propensity Score Matching analysis, there are two properties that must be satisfied. First, there should be enough common support in balancing the treated and the untreated group. Second, the balancing properties are satisfied. Estimation on the propensity score shown in the table 6 on the appendix consists of 54 propensity score estimated for each variable. Using Logit estimation, the probability of household getting Jamkesmas coverage is calculated.

Some variables show a positive coefficient, which means that it has higher probability to receive Jamkesmas. For example, Unconditional Cash Transfer (BBM BLT) is introduced as the compensation of subsidy cut on fuel; this might be the same eligibility requirement between Jamkesmas and BLT. Other variables that also indicate a positive coefficient are the size of household, the accessibility to clean water, the accessibility to piped water, the private clinic's accessibility to water, and the residency of household in rural area Unexpected positive sign appears from group that has far proximity with hospital. This means that the longer travel time might positively correlates with the probability to get Jamkesmas. There are also positive sign variables, although they are not statistically significant, that are interesting to note. There are private clinics that provide health check-up examination services. Many villages have public transport facilities, and their main road is made from asphalt. We expect that improving availability and infrastructure might broaden the allocation of Jamkesmas.

In contrast, there are variables that can significantly reduce the probability of Jamkesmas coverage. Variables, like Askes, Jamsostek and company insurance, have a negative sign and they are significant. This shows that households having other kind of insurance are less likely to receive Jamkesmas. Moreover, variables related to household assets, such asthe size of house $\left(\mathrm{m}^{2}\right)$ and the vehicle ownership also reduce the probability of Jamkesmas coverage. This is desirable because the richer households should have less probability to be covered by Jamkesmas. Interestingly, if one of the household members working in the government office, their propensity score is significantly lower. This could be because they are automatically covered by Askes. Moreover, the variable of the distance of village capital to district capital in kilometres has a negative value. This result is expected. Other distance and travel time related variables also have a negative sign, but not significant.

The availability of private clinics is determined by many variables. It is predicted that these variables have a positive sign. The accessibility of clean water is positive and significant. However, there is a variable that has a negative sign, i.e. the availability of dental service in private clinic.

In the first property of balancing common support, PSM analysis does not obtain lack of 
common support. Table 9 in the appendices reveals range of common support based on the number of observation whether it is off support or on support. In this table there are 36 out of 1953 are off support. It means 36 observation of treated group does not have match comparison group and dropped as a consequences. Meanwhile in the Figure 2 Distribution of the propensity score for treatment and control group, it shows the overlap pattern and also present how each group of treated are compared with some group of control (untreated). Furthermore in this matching step, 5 Nearest Neighborhood matching technique is employed.

In the balancing properties in table 10 in the Appendices, we can see that there are some variables do not satisfy balancing property. It means some of the differences between treated and control groups are large in those variables indicated by t-test show significant result. The author try to make some changes in the covariates by make some interaction variable but the significant feature in the t-test are unchanged. As a consequence, we need to get the new set of covariates that satisfied balancing properties. Due to the time constraint, author will limit the analysis here and will update with the newest balanced set of controls.

\section{Impact of Jamkesmas on Healthcare Utiliza- tion and Healthcare Expenditure}

Table 2 shows the result of the estimated impact of Jamkesmas on healthcare utilization using Propensity Score Matching method. In general, Jamkesmas' holders has a higher probability of using modern healthcare outpatient service than those without Jamkesmas. For total level, there is $2.9 \%$ of difference between the treated groups with the controlled groups. The probability of Jamkesmas' holders using public healthcare facility is slightly higher, that is 3.6\% difference. Hence, this shows how Jamkesmas could significantly impact the outpatient service usage.

Table 2. Estimated Impact of Jamkesmas on Healthcare Utilization and Health Expenditure (PSM)

\begin{tabular}{|c|c|c|c|c|c|c|c|c|}
\hline \multirow[b]{2}{*}{ VARIABLES } & \multicolumn{3}{|c|}{ Outpatient } & \multicolumn{3}{|c|}{ Inpatient } & \multirow{2}{*}{$\begin{array}{c}\text { Out of pock- } \\
\text { et ex- } \\
\text { penditure }\end{array}$} & \multirow{2}{*}{$\begin{array}{l}\text { Catastrophic health } \\
\text { spending } \\
\text { (more than } 15 \% \text { of } \\
\text { total expenditure) }\end{array}$} \\
\hline & All & Public & Private & All & Public & Private & & \\
\hline \multirow[t]{2}{*}{ Total } & $0.0290^{*}$ & $0.0359 * * *$ & -0.0053 & $0.0127^{*}$ & 0.0103 & 0.0036 & -0.0395 & 0.0000 \\
\hline & 0.0154 & 0.0130 & 0.0103 & 0.0076 & 0.0085 & 0.0044 & 0.2416 & 0.0090 \\
\hline \multirow[t]{2}{*}{ Quartile 1} & 0.0217 & 0.0177 & 0.0008 & -0.0031 & -0.0042 & 0.0043 & -0.2009 & 0.0083 \\
\hline & 0.02748 & 0.02306 & 0.01779 & 0.01279 & 0.01376 & 0.00429 & 0.33174 & 0.00583 \\
\hline \multirow[t]{2}{*}{ Quartile 2} & 0.0039 & 0.0067 & -0.0041 & 0.0274 & $0.0301^{*}$ & -0.0001 & -0.1645 & -0.0156 \\
\hline & 0.0318 & 0.0266 & 0.0220 & 0.0137 & 0.0173 & 0.0061 & 0.3936 & 0.0173 \\
\hline \multirow[t]{2}{*}{ Quartile 3} & 0.0505 & $0.0545^{* *}$ & 0.0105 & 0.0038 & 0.0029 & -0.0014 & -0.1454 & 0.0063 \\
\hline & 0.0318 & 0.0277 & 0.0208 & 0.0173 & 0.0207 & 0.0114 & 0.5257 & 0.0213 \\
\hline \multirow[t]{2}{*}{ Quartile 4} & 0.0647 & 0.0251 & 0.0310 & 0.0338 & 0.0258 & 0.0080 & 0.8784 & 0.0253 \\
\hline & 0.0400 & 0.0339 & 0.0297 & 0.0259 & 0.0269 & 0.0108 & 0.7853 & 0.0245 \\
\hline \multirow[t]{2}{*}{ Rural } & $0.0298^{*}$ & 0.0183 & 0.0119 & $0.0139^{*}$ & 0.0133 & 0.0024 & -0.1030 & -0.0024 \\
\hline & 0.0173 & 0.0144 & 0.0115 & 0.0079 & 0.0088 & 0.0029 & 0.2691 & 0.0085 \\
\hline \multirow[t]{2}{*}{ Urban } & 0.0221 & $0.0576^{* *}$ & -0.0272 & 0.0130 & 0.0136 & 0.0033 & -0.2923 & -0.0034 \\
\hline & 0.0290 & 0.0286 & 0.0183 & 0.0200 & 0.0221 & 0.0131 & 0.4442 & 0.0181 \\
\hline
\end{tabular}

Source: Author's calculation based on IFLS-East 2012 
As we can see in table 3, outcome of inpatient service utilization affected only in total level. The coefficient means that Jamkesmas's holder has a bigger probability with around 1.3 higher, but it is not statistically significant for public and private categories. Decomposition in the quartile groups shows no considerable difference. It is expected that the two lowest quartiles get the most of impact. However, the result does not meet this expectation. Moreover, the out of pocket health expenditure has a negative difference, although it is not statistically significant across the groups. Similar average treatment effect pattern also happens for the catastrophic health spending incidence. This finding is similar with the result from Suryanto et.al (2013) using previous IFLS 3, IFLS 4, Susenas 2009 and 2010 that health cost assistance to the poor has no significant influence on reducing catastrophic health expenditure. The one reason to explain is because the informal sector and who poor reducing their health related expenses and decide to use traditional or even inappropriate method.

Furthermore, the rural households who receive Jamkesmas have a higher probability to use the healthcare service in total level, both outpatient and inpatient service. However, this finding is different with the urban household receive Jamkesmas. The impact only occurs in the public outpatient service, but it has a bigger magnitude with 5.6\% ATT.

\section{CONCLUSION}

The aim of this study is to investigate the impact of Jamkesmas on health care utilization of in eastern Indonesia using IFLS-east data. The prior knowledge of about eastern Indonesia is they are relatively less developed than western part of Indonesia. Thus, they need more attention given their lack of infrastructure and health facilities and staff. We expect that Jamkesmas could reduce those barrier to access health services, with better targeting with better impact.
Moreover, allocation of Jamkesmas is more likely goes to quantile 1 and 2 of income group. It reflects that Jamkesmas program that are received by people targeted as eligibility criteria that Jamkesmas for the poor and near poor However, there is still some leakage with people in quartile 3 and 4 still get this health insurance. In addition, propensity score evaluation shows that people with longer distance and travelling time between village capital and district capital and health facilities like Puskesmas and private health provider has a less probability to get covered by Jamkesmas. In contrast with distance, if the availability of the Public Health Centre in that village is better, the higher probability of household participates in Jamkesmas program.

As a main purpose of this study, results show that in general utilization in general In general, Jamkesmas's holder has a bigger probability to utilize in healthcare service especially for public health center but only in outpatient. Inpatient is not statistically significant impacted by Jamkesmas in public or private groups but in total level. Furthermore, Jamkesmas has no significant impact on health spending both out of pocket expenditure and the probability of catastrophic health spending incidence.

Within those findings, however, we need to note some point that some factors might affect utilization of Jamkesmas which are not captured in the model. For example, the shock of when people is get chronic illness which will increase possibility for household to looking for Jamkesmas after get chronic condition. This study finds distance and travelling time variables are significant variables to reduce Jamkesmas coverage in Eastern region of Indonesia. Thus, improving more infrastructure or provision of transportation will help household participation in health insurance and health care utilization to get less time in travelling. 


\section{REFERENCES}

Aji, B., De Allegri, M.D., Souares, A., and Sauerborn, R. (2013). The Impact of Health Insurance Programs on Out-of-Pocket Expenditures in Indonesia: An Increase or a Decrease?. International Journal of Environmental Research and Public Health, 10(7), 2995-3013.

Erlyana, E., Damrongplasit, K.K., and Melnick, G. (2011). Expandinghealth Insurance To Increase Health Care Utilization: Will It Have Different Effects In Rural Vs Urban Areas?. Health Policy, 100, 273-81.

Government Regulation Number 40 Year 2004 Concerning National Social Security System (Republic of Indonesia).

Government Regulation Number 24 Year 2011 Concerning National Social Security Agency (Republic of Indonesia).

Harimurti, P., Pambudi, E., Pigazzini, A and Tandon, A. (2013). The nuts and bolts of Jamkesmas, Indonesia's government-financed health coverage program for the poor and near-poor, The World Bank, UNICO Studies Series 8, Washington. Viewed 4 June 2015, <http://wwwwds.worldbank.org/external/default/ WDSContentServer/WDSP/ IB/2013/03/25/000333037_20130325130 647/Rendered/PDF/749960REVISED00 00PUBLIC00Indonesia1.pdf $>$.

Hidayat, B., and Pokhrel, S. (2010). The Selection of an Appropriate Count Data Model for Modelling Health Insurance and Health Care Demand: Case of Indonesia, International Journal of Environmental Research and Public Health, 7(1), 927.

Satriawan, E., Priebe, J., Prima, R.A., and Howell, F. (2014). An introduction into the IFLS-East 2012: Sampling, questionnaires, maps and socio-economic background characteristics, TNP2K (Tim
Nasional Percepatan Penanggulangan Kemiskinan). Viewed 16 March 2015, <http://www.tnp2k.go.id/images/ uploads/downloads/WP\%2011a\%20Intro duction \%20to\%20IFLS\%20East\%202012. pdf>.

Sikoki, B., Witoelar, F., Strauss J., Meijer, E., and Suriastini N.W. (2013). Indonesia Family Life Survey East 2012: User's guide and field report. Yogyakarta: Survey METER.

Somanathan, A. (2008). The impact of price subsidies on child health care use: evaluation of the Indonesian healthcard. Viewed 20 March 2015, <https:// openknowledge.worldbank.org/bitstrea $\mathrm{m} /$ handle/10986/6682/wps4622.pdf?se quence $=1>$.

Sparrow, R., Suryahadi A., and Widyanti, W. Social Health Insurance for the Poor: Targeting and Impact of Indonesia's Askeskin Programme. Social Science $\mathcal{E}$ Medicine, 96, 264-71.

Suryanto, B.A., Mukti, A.G., Kusnanto, H., and Satriawan, E. (2015). The Role of Health Insurance, Borrowing and Aids to Pay for Health Care on Reducing Catastrophic Health Expenditure in Indonesia. Viewed 4 June 2015, http://papers.ssrn.com/sol3/papers.cf $\mathrm{m}$ ?abstract_id $=2586648$.

Vidyatama, Y., Miranti, R., and Resosudarmo, B.P. (2014). The role ofhealth insurance membership in health service utilization in Indonesia. Bulletin of Indonesian Economic Studies 50(3), 393-413.

World Bank. (2012), Jamkesmas health service fee waiver social assistance program and public expenditure review, World Bank Background Paper, viewed 4 June 2015,http://www.wds.worldbank.org /external/default/WDSContentServer/ WDSP/IB/2012/03/06/000356161_2012 0306010803/Rendered/PDF/673120WP 00PUBL0Background0Paper0040.pdf. 


\section{APPENDICES}

Table 3. Utilization of Outpatient and Inpatient at Public and Private Health Facility, IFLS East 2012

\begin{tabular}{lcccccc}
\hline & \multicolumn{3}{c}{ Outpatient } & \multicolumn{3}{c}{ Inpatient } \\
\cline { 2 - 6 } & All & Public & Private & All & Public & Private \\
\hline Quartile 1 (poorest) & 0.137 & 0.090 & 0.041 & 0.023 & 0.023 & 0.003 \\
Quartile 2 & 0.170 & 0.108 & 0.061 & 0.038 & 0.038 & 0.006 \\
Quartile 3 & 0.180 & 0.106 & 0.056 & 0.042 & 0.034 & 0.014 \\
Quartile 4 (richest) & 0.191 & 0.089 & 0.098 & 0.068 & 0.052 & 0.029 \\
Urban & 0.170 & 0.106 & 0.055 & 0.062 & 0.049 & 0.022 \\
Rural & 0.165 & 0.094 & 0.064 & 0.025 & 0.025 & 0.004 \\
Male & 0.139 & 0.084 & 0.047 & 0.035 & 0.029 & 0.010 \\
Female & 0.194 & 0.113 & 0.074 & 0.046 & 0.041 & 0.013 \\
Non-Papua Island & 0.167 & 0.094 & 0.063 & 0.036 & 0.03 & 0.012 \\
Papua Island & 0.166 & 0.114 & 0.052 & 0.055 & 0.053 & 0.011 \\
\hline Total & 0.167 & 0.099 & 0.061 & 0.040 & 0.035 & 0.012 \\
\hline
\end{tabular}

Source: Author's estimation based on IFLS-East 2012

Table 4. Distribution of Out-of-Pocket Health Expenditure, Non-Food Spending Share and Incidence of Catastrophic Spending Occurence (Percentages)

\begin{tabular}{lccc}
\hline & $\begin{array}{c}\text { Out of pocket } \\
\text { expenditure }\end{array}$ & $\begin{array}{c}\text { Share of } \\
\text { non-food spending }\end{array}$ & $\begin{array}{c}\text { Catastrophic health spend- } \\
\text { ing (more than 15\% of } \\
\text { total expenditure) }\end{array}$ \\
\hline Quartile 1 (poorest) & 0.807 & 33.171 & 0.005 \\
Quartile 2 & 1.208 & 38.100 & 0.015 \\
Quartile 3 & 1.350 & 40.913 & 0.016 \\
Quartile 4 (richest) & 1.945 & 46.421 & 0.026 \\
Urban & 1.837 & 47.403 & 0.024 \\
Rural & 0.844 & 32.848 & 0.008 \\
Male & 1.297 & 38.803 & 0.016 \\
Female & 1.227 & 39.114 & 0.013 \\
Non-Papua Island & 1.242 & 39.844 & 0.012 \\
Papua Island & 1.328 & 35.927 & 0.023 \\
\hline Total & 1.261 & 38.962 & 0.015 \\
\hline
\end{tabular}

Source: Author's estimation based on IFLS-East 2012

Table 5. Health Expenditure Regression, 2012, Ordinary Least Square

\begin{tabular}{lcc}
\hline VARIABLES & Coefficient & Standard Error \\
\hline JAMKESMAS & -339.617 & $(3,324.383)$ \\
ASKES & $9,486.302$ & $(6,865.709)$ \\
JAMSOSTEK & $-10,329.332$ & $(8,109.217)$ \\
Company insurance & 799.733 & $(8,378.626)$ \\
Company clinic & -368.546 & $(7,594.197)$ \\
Private Insurance & $17,963.538$ & $(18,190.075)$ \\
Unconditional Cash Transfer (BBMBLT) & $-5,251.233^{*}$ & $(2,147.330)$ \\
Female household head & $-9,737.538+$ & $(5,203.506)$ \\
Household head education & 24.536 & $(691.828)$ \\
Household size & $-4,677.177^{* *}$ & $(1,367.664)$ \\
Share under 6 female & $-18,317.522$ & $(16,172.800)$ \\
Share under 6 male & $-6,671.307$ & $(13,702.742)$ \\
Share 6 to 17male & $-10,869.672$ & $(11,613.777)$ \\
Share 18 to 60 female & $6,338.932$ & $(18,026.549)$ \\
Share 60 up female & $-16,677.414$ & $(11,078.186)$ \\
Share 60 up male & $-5,552.574$ & $(15,899.435)$ \\
Owned House & $-5,484.773$ & $(5,955.024)$ \\
House size $\left(\mathrm{m}^{2}\right)$ & $90.276+$ & $(49.385)$ \\
Own water access & -842.489 & $(3,132.538)$ \\
\end{tabular}


Own vehicle

$1,593.262$

$(6,333.295)$

Own piped water

$-9,784.529$

$(6,973.282)$

Self employed

$9,808.427^{*}$

$(4,991.176)$

Self Employed with permanent workers

$4,161.914$

$(16,331.479)$

Self Employed with permanent workers

$(6,209.129)$

Working part-time

$6,710.701$

$5,266.362$

$(5,049.198)$

Government official

$-915.305$

Casual worker in agriculture

$-3,825.328$

$(6,811.227)$

$(4,564.503)$

Casual worker non in agriculture

$-7,978.930$

$(7,309.612)$

Puskesmas has a water access

$6,487.737$

$(5,506.652)$

Puskesmas offer check-up/health examination

$6,404.672$

$(4,008.677)$

Puskesmas offer inpatient service

$-3,947.382$

$(4,974.984)$

$-3,719.917$

Puskesmas offer dental service

$5,957.999+$

$(6,357.939)$

Puskesmas has a pharmacy

$(3,070.323)$

Private clinic has an electricity

$7,731.782^{*}$

$(3,715.223)$

$-756.747$

$(6,328.137)$

Private clinic provides an inpatient services

$-10,592.019$

$(17,199.239)$

Private clinic provides dental services

$17,211.214+$

$(10,207.628)$

Private clinic has more than 1 medical staff

$19,429.780$

$(19,735.290)$

Private clinic's medical staff number

Private clinic provide check-up/health examination services

$6,933.733$

$-14,558.457^{*}$

$(13,742.041)$

Village has public transport facilities

$4,328.199$

$(6,050.481)$

Village main road from asphalt

Distance of district capital from village office $(\mathrm{km})$

$-1,000.469$

30.379

$(3,890.562)$

Distance of bus station from village office $(\mathrm{km})$

47.645

(.279)

(33.255)

$(77.010)$

Travel time to nearest PUSKESMAS from village office (hours)

$-20,912.816^{* *}$

$(6,869.707)$

$14,211.392^{* *}$

$(5,373.004)$

Travel time to nearest private clinic from village office (hours)

$-18,367.031$

$(29,020.811)$

Travel time to nearest hospital from village office (hours)

917.153

rural

$-14,109.628+$

(646.347)

$(7,360.844)$

Constant

$15,267.004$

$(14,286.709)$

Observations

2,009

R-squared

0.122

Robust standard errors in parentheses

${ }^{* *} \mathrm{p}<0.01,{ }^{*} \mathrm{p}<0.05,+\mathrm{p}<0.1$

Table 6. Propensity Score Function, Probability of Jamkesmas Coverage (Logit Estimates)

\begin{tabular}{lrrr}
\hline VARIABLES & Coefficient & Standard Error & $P>|z|$ \\
\hline ASKES & $-0.8039761^{* * *}$ & 0.250713 & 0.001 \\
JAMSOSTEK & $-0.6501821^{* *}$ & 0.2969173 & 0.029 \\
Company insurance & $-1.140431^{*}$ & 0.6489512 & 0.079 \\
Company clinic & -0.1234484 & 0.5685474 & 0.828 \\
Private Insurance & -1.020746 & 0.7798305 & 0.191 \\
Unconditional Cash Transfer (BBMBLT) & $0.9906677^{* * *}$ & 0.1352175 & 0 \\
Female household head & -0.0704081 & 0.1917069 & 0.713 \\
Household head education & -0.0012435 & 0.0158683 & 0.938 \\
Household size & $0.2013327^{* * *}$ & 0.0348588 & 0 \\
Share under 6 female & -0.7868103 & 0.5262906 & 0.135 \\
Share under 6 male & -0.2807972 & 0.5155342 & 0.586 \\
Share 6 to 17male & 0.6789076 & 0.418534 & 0.105 \\
Share 18 to 60 female & 0.1915376 & 0.3982037 & 0.631 \\
Share 60 up female & 1.020724 & 0.4501642 & 0.023 \\
Share 60 up male & -0.3541693 & 0.5264139 & 0.501 \\
Owned House & 0.1857353 & 0.1565389 & 0.235 \\
House size $\left(m^{2}\right)$ & $-0.003937^{* * *}$ & 0.0015075 & 0.009 \\
Own water access & $0.256806^{* *}$ & 0.1448193 & 0.076 \\
Own vehicle & $-0.0985058^{* *}$ & 0.1461105 & 0.5
\end{tabular}

The Impact of Jamkesmas on Healthcare Utilization... (Novat Pugo Sambodo) 
Own piped water

Self employed

Self Employed with permanent workers

Self Employed with permanent workers

Working part-time

Casual worker in agriculture

Casual worker non in agriculture

Puskesmas has a water access

Puskesmas offer check-up/health examination

Puskesmas offer inpatient service

Puskesmas offer dental service

Puskesmas has a pharmacy

Private clinic has an electricity

Private clinic has an access to water

Private clinic provides an inpatient services

Private clinic provides dental services

Private clinic has more than 1 medical staff

Private clinic's medical staff number

Private clinic provide check-up/health examination services

Village has public transport facilities

Village main road from asphalt

Distance of district capital from village office $(\mathrm{km})$

Distance of bus station from village office $(\mathrm{km})$

Travel time to nearest PUSKESMAS from village office (hours)

Travel time to nearest private clinic from village office (hours)

Travel time to nearest traditional clinic from village office (hours)

Travel time to nearest hospital from village office (hours)

rural

Kalimantan Timur

Sulawesi Tenggara

Maluku Utara

Papua Barat

Papua

Constant

Number of obs $=1953$

LR chi2(54) = 678.37

Prob> chi $2 \quad=\quad 0.0000$

Log likelihood $=\quad-948.49491$

Pseudo R2 = 0.2634

Source: Author's estimation based on IFLS-East 2012
Government official

Maluku

\begin{tabular}{rrr}
$0.3635692^{*}$ & 0.2124169 & 0.087 \\
0.2033447 & 0.1463234 & 0.165 \\
0.2259828 & 0.5190333 & 0.663 \\
-0.0912295 & 0.1488595 & 0.54 \\
0.0218014 & 0.1466572 & 0.882 \\
$-0.3719803^{*}$ & 0.2193433 & 0.09 \\
-0.1483717 & 0.3833932 & 0.699 \\
-0.0438928 & 0.3062193 & 0.886 \\
-0.1455417 & 0.1941079 & 0.453 \\
0.5217562 & 0.188935 & 0.006 \\
0.2094606 & 0.1876386 & 0.264 \\
-0.2494966 & 0.2128469 & 0.241 \\
-0.4318904 & 0.2567635 & 0.093 \\
0.2716368 & 0.3095453 & 0.38 \\
$0.4141801^{* *}$ & 0.2117421 & 0.05 \\
-0.7895023 & 0.6733281 & 0.241 \\
$-2.863848^{* * *}$ & 0.6773531 & 0 \\
-0.0716691 & 0.5759863 & 0.901 \\
-0.7292938 & 0.4800033 & 0.129 \\
0.817454 & 0.302973 & 0.007 \\
0.4014857 & 0.2259131 & 0.076 \\
0.2893342 & 0.2040933 & 0.156 \\
$-0.0023017^{*}$ & 0.0012272 & 0.061 \\
-0.0012068 & 0.0038828 & 0.756 \\
-0.4524845 & 0.5309834 & 0.394 \\
-0.1529145 & 0.484605 & 0.752 \\
-0.5236731 & 0.9445133 & 0.579 \\
$0.1859342^{* * *}$ & 0.0477327 & 0 \\
$1.021743^{* * *}$ & 0.2392876 & 0 \\
$-1.393772^{* * *}$ & 0.3369993 & 0 \\
$-1.053196^{* * *}$ & 0.2440458 & 0 \\
$-1.330475^{* * *}$ & 0.317391 & 0 \\
$-1.978016^{* * *}$ & 0.2771026 & 0 \\
-0.3076135 & 0.2586118 & 0.234 \\
0.0107798 & 0.2345287 & 0.963 \\
-1.249778 & 0.7074271 & 0.077 \\
\hline & & \\
\hline
\end{tabular}

Table 7. Impact of Jamkesmas on Healthcare Utilization (OLS)

\begin{tabular}{|c|c|c|c|c|c|c|c|c|c|}
\hline VARIABLES & $\begin{array}{c}\text { outpa- } \\
\text { tient }\end{array}$ & $\begin{array}{l}\text { outpub- } \\
\text { lic }\end{array}$ & $\begin{array}{l}\text { outpri- } \\
\text { vate }\end{array}$ & $\begin{array}{c}\text { inpa- } \\
\text { tient }\end{array}$ & $\begin{array}{l}\text { inpub- } \\
\text { lic }\end{array}$ & $\begin{array}{l}\text { inpri- } \\
\text { vate }\end{array}$ & $\begin{array}{c}\text { wmedi- } \\
\text { cal }\end{array}$ & $\begin{array}{c}\text { ch_oop } \\
10\end{array}$ & $\begin{array}{c}\text { ch_oop } \\
15\end{array}$ \\
\hline $\begin{array}{l}\text { Quartile } 1 \text { (poor- } \\
\text { est) }\end{array}$ & $\begin{array}{r}0.027 \\
(0.028)\end{array}$ & $\begin{array}{r}0.024 \\
(0.025)\end{array}$ & $\begin{array}{r}-0.004 \\
(0.014)\end{array}$ & $\begin{array}{r}-0.001 \\
(0.011)\end{array}$ & $\begin{array}{r}-0.003 \\
(0.012)\end{array}$ & $\begin{array}{r}0.004 \\
(0.003)\end{array}$ & $\begin{array}{r}-0.119 \\
(0.219)\end{array}$ & $\begin{array}{r}0.001 \\
(0.014)\end{array}$ & $\begin{array}{r}0.007 \\
(0.005)\end{array}$ \\
\hline Quartile 2 & $\begin{array}{l}-0.003 \\
(0.034)\end{array}$ & $\begin{array}{r}-0.012 \\
(0.031)\end{array}$ & $\begin{array}{r}-0.005 \\
(0.018)\end{array}$ & $\begin{array}{r}0.012 \\
(0.014)\end{array}$ & $\begin{array}{r}0.002 \\
(0.016)\end{array}$ & $\begin{array}{r}0.010 \\
(0.010)\end{array}$ & $\begin{array}{r}-0.144 \\
(0.348)\end{array}$ & $\begin{array}{r}-0.009 \\
(0.016)\end{array}$ & $\begin{array}{r}-0.017 \\
(0.015)\end{array}$ \\
\hline Quartile 3 & $\begin{array}{r}0.024 \\
(0.034)\end{array}$ & $\begin{array}{r}0.046 \\
(0.034)\end{array}$ & $\begin{array}{r}-0.000 \\
(0.016)\end{array}$ & $\begin{array}{r}0.013 \\
(0.015)\end{array}$ & $\begin{array}{r}0.031 \\
(0.025)\end{array}$ & $\begin{array}{l}-0.008 \\
(0.008)\end{array}$ & $\begin{array}{l}-0.622^{*} \\
(0.312)\end{array}$ & $\begin{array}{l}-0.032^{*} \\
(0.016)\end{array}$ & $\begin{array}{r}-0.013 \\
(0.012)\end{array}$ \\
\hline $\begin{array}{l}\text { Quartile } 4 \text { (Rich- } \\
\text { est) }\end{array}$ & $\begin{array}{r}0.067 \\
(0.046)\end{array}$ & $\begin{array}{r}0.058 \\
(0.037)\end{array}$ & $\begin{array}{r}0.002 \\
(0.033)\end{array}$ & $\begin{array}{r}0.038 \\
(0.033)\end{array}$ & $\begin{array}{r}0.043 \\
(0.032)\end{array}$ & $\begin{array}{r}-0.019 \\
(0.015)\end{array}$ & $\begin{array}{r}0.502 \\
(0.752)\end{array}$ & $\begin{array}{r}0.037 \\
(0.040)\end{array}$ & $\begin{array}{r}0.011 \\
(0.030)\end{array}$ \\
\hline Rural & $\begin{array}{r}0.029 \\
(0.020)\end{array}$ & $\begin{array}{r}0.016 \\
(0.016)\end{array}$ & $\begin{array}{r}0.013 \\
(0.012)\end{array}$ & $\begin{array}{l}0.016^{*} \\
(0.006)\end{array}$ & $\begin{array}{l}0.013+ \\
(0.008)\end{array}$ & $\begin{array}{l}0.003+ \\
(0.002)\end{array}$ & $\begin{array}{r}0.000 \\
(0.178)\end{array}$ & $\begin{array}{r}-0.002 \\
(0.009)\end{array}$ & $\begin{array}{r}-0.001 \\
(0.007)\end{array}$ \\
\hline Urban & $\begin{array}{r}0.007 \\
(0.030)\end{array}$ & $\begin{array}{r}0.027 \\
(0.031)\end{array}$ & $\begin{array}{r}-0.017 \\
(0.020)\end{array}$ & $\begin{array}{r}0.014 \\
(0.024)\end{array}$ & $\begin{array}{r}0.021 \\
(0.027)\end{array}$ & $\begin{array}{l}-0.004 \\
(0.013)\end{array}$ & $\begin{array}{r}-0.227 \\
(0.521)\end{array}$ & $\begin{array}{r}-0.004 \\
(0.027)\end{array}$ & $\begin{array}{r}-0.009 \\
(0.023)\end{array}$ \\
\hline
\end{tabular}




\begin{tabular}{lrrrrrrrrr} 
Papua & $0.071^{*}$ & $0.059^{*}$ & 0.023 & 0.019 & $0.046+$ & -0.011 & -0.218 & -0.003 & -0.023 \\
& $(0.034)$ & $(0.028)$ & $(0.025)$ & $(0.021)$ & $(0.028)$ & $(0.008)$ & $(0.541)$ & $(0.030)$ & $(0.022)$ \\
Non Papua & 0.018 & 0.009 & 0.002 & 0.010 & 0.003 & 0.004 & -0.057 & -0.000 & 0.000 \\
& $(0.019)$ & $(0.018)$ & $(0.011)$ & $(0.010)$ & $(0.010)$ & $(0.006)$ & $(0.240)$ & $(0.013)$ & $(0.010)$ \\
Total & $0.028+$ & $0.028+$ & -0.004 & $0.015+$ & 0.015 & 0.001 & -0.234 & -0.013 & -0.010 \\
& $(0.017)$ & $(0.015)$ & $(0.010)$ & $(0.008)$ & $(0.010)$ & $(0.004)$ & $(0.200)$ & $(0.011)$ & $(0.008)$ \\
\hline
\end{tabular}

Source: Author's estimation based on IFLS-East 2012

Table 8. Descriptive Statistics

\begin{tabular}{|c|c|c|c|c|c|}
\hline Variables & Observation & $\begin{array}{c}\text { mea } \\
\mathrm{n}\end{array}$ & $\begin{array}{l}\text { Standar Devia- } \\
\text { tion }\end{array}$ & $\min$ & $\max$ \\
\hline Outpatient total & 2,411 & $\begin{array}{l}0.167 \\
0.098\end{array}$ & 0.243 & 0 & 1 \\
\hline Outpatient public & 2,401 & $\begin{array}{c}7 \\
0.062\end{array}$ & 0.200 & 0 & 1 \\
\hline Outpatient private & 2,401 & $\begin{array}{c}8 \\
0.038\end{array}$ & 0.165 & 0 & 1 \\
\hline Inpatient total & 2,411 & $\begin{array}{c}6 \\
0.035\end{array}$ & 0.119 & 0 & 1 \\
\hline Inpatient public & 2,357 & $\begin{array}{c}5 \\
0.011\end{array}$ & 0.125 & 0 & 1 \\
\hline Inpatient private & 2,357 & 0 & 0.0743 & 0 & $\begin{array}{c}1 \\
73.6\end{array}$ \\
\hline Out of pocket health expenditure Share & 2,411 & $\begin{array}{l}1.291 \\
0.028\end{array}$ & 3.550 & 0 & 7 \\
\hline Catastrophic health spending $10 \%$ & 2,411 & $\begin{array}{c}2 \\
0.013\end{array}$ & 0.166 & 0 & 1 \\
\hline Catastrophic health spending $15 \%$ & 2,411 & 7 & 0.116 & 0 & 1 \\
\hline illness & 2,411 & 0.725 & 0.296 & 0 & 1 \\
\hline $\begin{array}{l}\text { JAMKESMAS } \\
\text { ASKES }\end{array}$ & $\begin{array}{l}2,411 \\
2,411\end{array}$ & $\begin{array}{l}0.361 \\
0.129 \\
0.056\end{array}$ & $\begin{array}{l}0.480 \\
0.335\end{array}$ & $\begin{array}{l}0 \\
0\end{array}$ & $\begin{array}{l}1 \\
1\end{array}$ \\
\hline JAMSOSTEK & 2,411 & $\begin{array}{c}8 \\
0.018\end{array}$ & 0.232 & 0 & 1 \\
\hline Company insurance & 2,411 & $\begin{array}{c}7 \\
0.014\end{array}$ & 0.135 & 0 & 1 \\
\hline Private insurance & 2,411 & $\begin{array}{c}9 \\
0.013\end{array}$ & 0.121 & 0 & 1 \\
\hline Company clinic & 2,411 & 7 & 0.116 & 0 & 1 \\
\hline Household head female & 2,411 & 0.161 & 0.367 & 0 & 1 \\
\hline HH head education & 2,411 & 7.737 & 4.569 & 0 & 18 \\
\hline Household size & 2,411 & $\begin{array}{l}4.288 \\
0.066\end{array}$ & 2.057 & 1 & $\begin{array}{c}16 \\
0.66\end{array}$ \\
\hline Share under 6 female & 2,411 & $\begin{array}{c}8 \\
0.070\end{array}$ & 0.119 & 0 & $\begin{array}{c}7 \\
0.60\end{array}$ \\
\hline Share under 6 male & 2,411 & 5 & 0.122 & 0 & 0 \\
\hline Share 6 to 17 female & 2,411 & 0.117 & 0.161 & 0 & 1 \\
\hline Share 6 to 17 male & 2,411 & 0.119 & 0.155 & 0 & 1 \\
\hline Share 18 to 60 female & 2,411 & 0.290 & 0.186 & 0 & 1 \\
\hline Share 18 to 60 male & 2,411 & $\begin{array}{l}0.261 \\
0.046\end{array}$ & 0.205 & 0 & 1 \\
\hline Share 60 up female & 2,411 & $\begin{array}{c}5 \\
0.039\end{array}$ & 0.151 & 0 & 1 \\
\hline Share 60 up male & 2,411 & 2 & 0.119 & 0 & 1 \\
\hline Household own BBM BLT card & 2,400 & 0.229 & 0.420 & 0 & 1 \\
\hline Owns house & 2,411 & 0.763 & 0.425 & 0 & 1 \\
\hline House size $\left(\mathrm{m}^{2}\right)$ & 2,410 & 62.25 & 49.92 & 4 & 800 \\
\hline Owns water access & 2,411 & 0.307 & 0.461 & 0 & 1 \\
\hline
\end{tabular}


Household has a vehicle

self employed

Working Part Time

Self-employed with permanent workers

Private Worker

Unpaid family worker

Casual worker in agriculture

Casual worker not in agriculture

Puskesmas has an electricity

Puskesmas has a water access

Puskesmas has a pharmacy

Puskesmas offer inpatient service

Puskesmas offer inpatient service other than birth

Puskesmas offer check-up/health examination

Puskesmas offer dental service

Private clinic has an electricity

Private clinic has an access to water

Private clinic provide check-up/health examination services

Private clinic provides dental services

Private clinic has more than 1 medical staff

Private clinic's number of medical staff

Village has public transport facilities

Village main road from asphalt

Distance of bus station from village office $(\mathrm{km})$

Distance of district capital from village office $(\mathrm{km})$

Travel time to nearest PUSKESMAS from village

office (hours)

Travel time to nearest private clinic from village office (hours)

Travel time to nearest traditional clinic from village office (hours)

Travel time to nearest Hospital from village office (hours)

Travel time to nearest POSYANDU from village office (hours)

rural

HH size square

Papua

Source: Author's estimation based on IFLS-East 2012
Government Official

Private clinic provides an inpatient services

\begin{tabular}{|c|c|c|c|c|}
\hline 2,411 & 0.316 & 0.465 & 0 & 1 \\
\hline 2,411 & 0.287 & 0.453 & 0 & 1 \\
\hline \multirow[t]{2}{*}{2,411} & 0.484 & 0.500 & 0 & 1 \\
\hline & 0.015 & & & \\
\hline 2,411 & 3 & 0.123 & 0 & 1 \\
\hline 2,411 & 0.155 & 0.362 & 0 & 1 \\
\hline 2,411 & 0.202 & 0.402 & 0 & 1 \\
\hline \multirow[t]{2}{*}{2,411} & 0.388 & 0.487 & 0 & 1 \\
\hline & 0.020 & & & \\
\hline \multirow[t]{2}{*}{2,411} & 7 & 0.143 & 0 & 1 \\
\hline & 0.037 & & & \\
\hline 2,411 & 7 & 0.191 & 0 & 1 \\
\hline 2,411 & 0.847 & 0.360 & 0 & 1 \\
\hline 2,411 & 0.320 & 0.467 & 0 & 1 \\
\hline 2,411 & 0.895 & 0.306 & 0 & 1 \\
\hline 2,384 & 0.305 & 0.461 & 0 & 1 \\
\hline 2,384 & 0.263 & 0.441 & 0 & 1 \\
\hline 2,384 & 0.570 & 0.495 & 0 & 1 \\
\hline 2,384 & 0.613 & 0.487 & 0 & 1 \\
\hline 2,411 & 0.858 & 0.349 & 0 & 1 \\
\hline \multirow[t]{2}{*}{2,411} & 0.226 & 0.419 & 0 & 1 \\
\hline & 0.027 & & & \\
\hline \multirow[t]{2}{*}{2,276} & 7 & 0.164 & 0 & 1 \\
\hline & 0.055 & & & \\
\hline \multirow[t]{2}{*}{2,276} & 8 & 0.230 & 0 & 1 \\
\hline & 0.026 & & & \\
\hline \multirow[t]{2}{*}{2,276} & 4 & 0.160 & 0 & 1 \\
\hline & 0.078 & & & \\
\hline 2,411 & 8 & 0.269 & 0 & 1 \\
\hline 2,411 & 1.102 & 0.432 & 1 & 4 \\
\hline 2,411 & 0.809 & 0.393 & 0 & 1 \\
\hline 2,411 & 0.687 & 0.464 & 0 & 1 \\
\hline 2,323 & 9.728 & 26.69 & 0.01000 & 200 \\
\hline 2,213 & 56.03 & 83.42 & 0.500 & 450 \\
\hline 2,411 & 0.450 & 1.898 & 0 & 16 \\
\hline \multirow[t]{2}{*}{2,411} & 0.254 & 0.801 & 0 & 6 \\
\hline & 0.081 & & & 0.50 \\
\hline 2,411 & 3 & 0.0752 & 0 & 0 \\
\hline 2,411 & 0.697 & 2.828 & 0 & 24 \\
\hline 2,411 & 0.118 & 0.345 & 0 & 3 \\
\hline 2,411 & 0.706 & 0.456 & 0 & 1 \\
\hline 2,411 & 22.62 & 22.43 & 1 & 256 \\
\hline 2,411 & 0.285 & 0.451 & 0 & 1 \\
\hline
\end{tabular}

Table 9. Common Support by Number of Observations using 5 Nearest Neighborhood

\begin{tabular}{lllr}
\hline & \multicolumn{3}{c}{ Common Support } \\
\cline { 2 - 4 } \multicolumn{1}{c}{ Treatment Assignment } & Off support & On Support & Total \\
\hline Untreated & 0 & 1229 & 1229 \\
Treated & 36 & 688 & 724 \\
\hline Total & 36 & 1917 & 1953 \\
\hline
\end{tabular}


Figure 2 Distribution of the propensity score for treatment and control group using five nearest neighbourhood

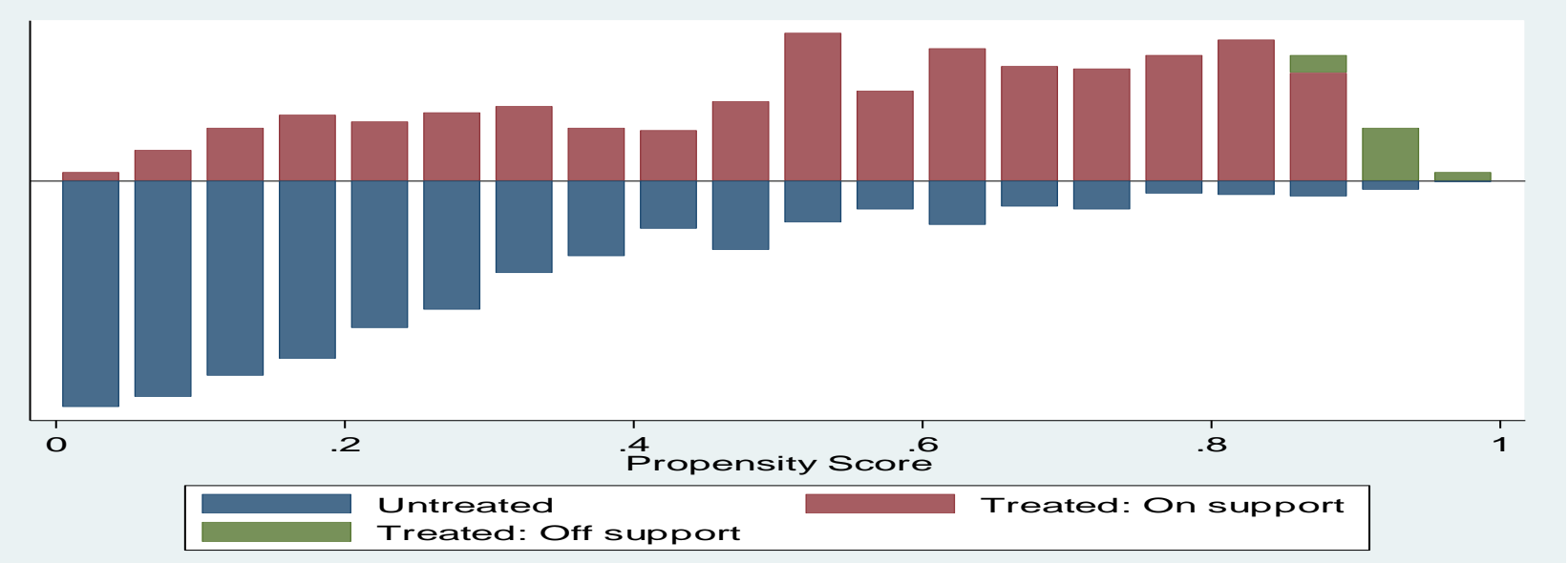

Source: Author's estimation based on IFLS-East 2012

Table 10. Balancing Properties of the Matched Samples using 5 Nearest Neighborhood

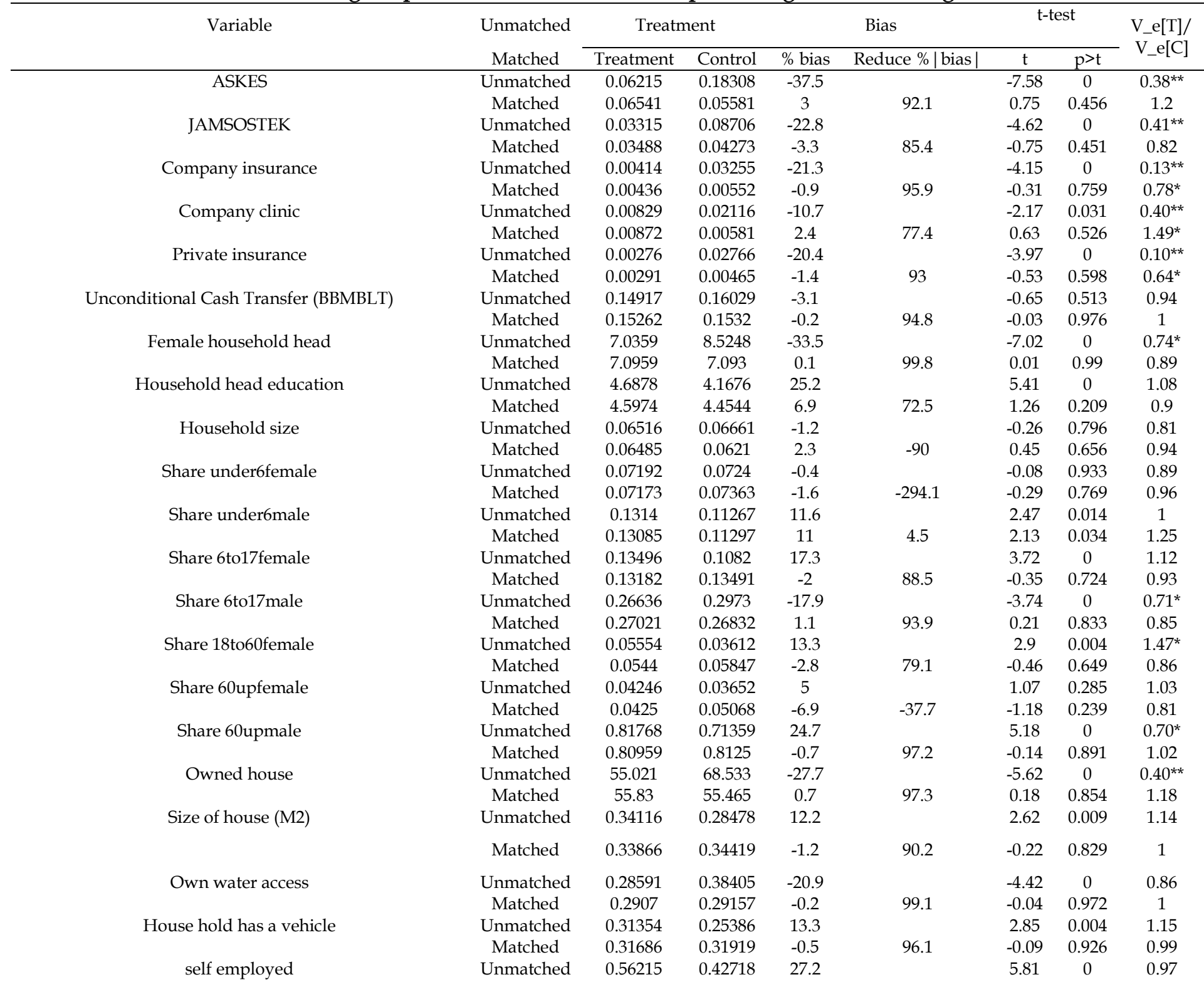


Working Part Time

Self-employed with permanent workers

Government Official

Private Worker

Unpaid family worker

Casual worker in agriculture

Casual worker not in agriculture

Puskesmas has an electricity

Puskesmas has a water access

Puskesmas has a pharmacy

Puskesmas offer inpatient service

Puskesmas offer inpatient service other than birth

Puskesmas offer check-up/health examination

Puskesmas offer dental service

Private clinic has an electricity

Private clinic has an access to water

Private clinic provides an inpatient services

Private clinic provide check-up/health examination services

Private clinic provides dental services

Private clinic has more than 1 medical staff

Private clinic's medical staff number

Village has public transport facilities

Village main road from asphalt

Distance of bus station from village office $(\mathrm{km})$

Distance of district capital from village office $(\mathrm{km})$

Travel time to nearest Puskesmas from village office (hours)

Travel time to nearest private clinic from village office (hours)

Travel time to nearest traditional clinic from village office (hours)

Travel time to nearest Hospital from village office (hours)

Travel time to nearest Posyandu from village office (hours)

\begin{tabular}{|c|c|c|c|c|c|c|c|}
\hline Matched & 0.54651 & 0.54273 & 0.8 & 97.2 & 0.14 & 0.888 & 0.99 \\
\hline Unmatched & 0.00967 & 0.02116 & -9.3 & & -1.9 & 0.057 & $0.46^{* *}$ \\
\hline Matched & 0.01017 & 0.01395 & -3.1 & 67.1 & -0.64 & 0.521 & $0.74^{*}$ \\
\hline Unmatched & 0.10221 & 0.20423 & -28.6 & & -5.9 & 0 & $0.57^{*}$ \\
\hline Matched & 0.10756 & 0.09099 & 4.6 & 83.8 & 1.03 & 0.304 & 1.24 \\
\hline Unmatched & 0.19751 & 0.2441 & -11.2 & & -2.38 & 0.018 & 0.85 \\
\hline Matched & 0.20058 & 0.20581 & -1.3 & 88.8 & -0.24 & 0.81 & 0.97 \\
\hline Unmatched & 0.4779 & 0.34093 & 28.1 & & 6.04 & 0 & 1.06 \\
\hline Matched & 0.4593 & 0.43779 & 4.4 & 84.3 & 0.8 & 0.423 & 0.98 \\
\hline Unmatched & 0.0221 & 0.02034 & 1.2 & & 0.26 & 0.794 & 1.09 \\
\hline Matched & 0.0218 & 0.0218 & 0 & 100 & 0 & 1 & 1 \\
\hline Unmatched & 0.04144 & 0.03173 & 5.2 & & 1.12 & 0.262 & $1.30^{*}$ \\
\hline Matched & 0.0436 & 0.05174 & -4.3 & 16.1 & -0.71 & 0.479 & 0.85 \\
\hline Unmatched & 0.8895 & 0.90724 & -5.9 & & -1.27 & 0.206 & 1.15 \\
\hline Matched & 0.89099 & 0.92762 & -12.1 & -106.5 & -2.37 & 0.018 & $1.36^{*}$ \\
\hline Unmatched & 0.22928 & 0.41904 & -41.4 & & -8.66 & 0 & $0.69^{*}$ \\
\hline Matched & 0.23983 & 0.22791 & 2.6 & 93.7 & 0.52 & 0.602 & 1.06 \\
\hline Unmatched & 0.8453 & 0.91456 & -21.4 & & -4.73 & 0 & $1.66^{*}$ \\
\hline Matched & 0.85029 & 0.83983 & 3.2 & 84.9 & 0.54 & 0.592 & 0.98 \\
\hline Unmatched & 0.43232 & 0.26444 & 35.8 & & 7.75 & 0 & 1.23 \\
\hline Matched & 0.41424 & 0.44244 & -6 & 83.2 & -1.06 & 0.291 & 0.98 \\
\hline Unmatched & 0.33149 & 0.22295 & 24.4 & & 5.3 & 0 & $1.27^{*}$ \\
\hline Matched & 0.32122 & 0.31366 & 1.7 & 93 & 0.3 & 0.764 & 1.02 \\
\hline Unmatched & 0.58149 & 0.60862 & -5.5 & & -1.18 & 0.238 & 1.04 \\
\hline Matched & 0.57994 & 0.55727 & 4.6 & 16.4 & 0.85 & 0.396 & 0.99 \\
\hline Unmatched & 0.6105 & 0.65419 & -9.1 & & -1.94 & 0.052 & 1.05 \\
\hline Matched & 0.60174 & 0.5936 & 1.7 & 81.4 & 0.31 & 0.758 & 1.01 \\
\hline Unmatched & 0.90746 & 0.93653 & -10.9 & & -2.37 & 0.018 & $1.40^{*}$ \\
\hline Matched & 0.90988 & 0.91628 & -2.4 & 78 & -0.42 & 0.674 & 1.04 \\
\hline Unmatched & 0.16022 & 0.29455 & -32.5 & & -6.74 & 0 & $0.65^{*}$ \\
\hline Matched & 0.1657 & 0.15203 & 3.3 & 89.8 & 0.69 & 0.489 & 1.09 \\
\hline Unmatched & 0.00552 & 0.04638 & -25.9 & & -5.04 & 0 & $0.18^{* *}$ \\
\hline Matched & 0.00581 & 0.00436 & 0.9 & 96.4 & 0.38 & 0.705 & $1.34^{*}$ \\
\hline Unmatched & 0.08011 & 0.0537 & 10.6 & & 2.31 & 0.021 & $1.45^{*}$ \\
\hline Matched & 0.0843 & 0.06105 & 9.3 & 11.9 & 1.66 & 0.097 & 1.24 \\
\hline Unmatched & 0.00691 & 0.04394 & -23.7 & & -4.64 & 0 & $0.22^{* *}$ \\
\hline Matched & 0.00727 & 0.00698 & 0.2 & 99.2 & 0.06 & 0.949 & 1.04 \\
\hline Unmatched & 0.01796 & 0.13588 & -45.4 & & -8.87 & 0 & $0.19^{* *}$ \\
\hline Matched & 0.0189 & 0.02267 & -1.5 & 96.8 & -0.49 & 0.624 & 0.83 \\
\hline Unmatched & 1.0166 & 1.1798 & -39.2 & & -7.61 & 0 & $0.13^{* *}$ \\
\hline Matched & 1.0174 & 1.0227 & -1.3 & 96.8 & -0.54 & 0.587 & 1.18 \\
\hline Unmatched & 0.88398 & 0.80716 & 21.4 & & 4.44 & 0 & $0.69^{*}$ \\
\hline Matched & 0.87936 & 0.86744 & 3.3 & 84.5 & 0.66 & 0.507 & 0.93 \\
\hline Unmatched & 0.73757 & 0.74044 & -0.7 & & -0.14 & 0.889 & 1.03 \\
\hline Matched & 0.73401 & 0.74128 & -1.7 & -153.2 & -0.31 & 0.76 & 1 \\
\hline Unmatched & 10.58 & 10.986 & -1.4 & & -0.3 & 0.763 & $0.76^{*}$ \\
\hline Matched & 10.845 & 11.625 & -2.8 & -91.9 & -0.52 & 0.6 & 0.92 \\
\hline Unmatched & 51.431 & 58.606 & -8.8 & & -1.8 & 0.072 & $0.47^{* *}$ \\
\hline Matched & 51.517 & 49.744 & 2.2 & 75.3 & 0.49 & 0.622 & 0.96 \\
\hline Unmatched & 0.16867 & 0.33233 & -21.2 & & -4.31 & 0 & $0.45^{* *}$ \\
\hline Matched & 0.17265 & 0.18242 & -1.3 & 94 & -0.29 & 0.775 & 0.86 \\
\hline Unmatched & 0.16664 & 0.27796 & -14.4 & & -2.93 & 0.003 & $0.43^{* *}$ \\
\hline Matched & 0.16771 & 0.18823 & -2.7 & 81.6 & -0.59 & 0.555 & 0.87 \\
\hline Unmatched & 0.0788 & 0.09231 & -17.8 & & -3.69 & 0 & $0.64^{*}$ \\
\hline Matched & 0.07863 & 0.07695 & 2.2 & 87.5 & 0.47 & 0.642 & 1.08 \\
\hline Unmatched & 0.87396 & 0.81623 & 1.9 & & 0.4 & 0.692 & $0.63^{*}$ \\
\hline Matched & 0.87936 & 1.0341 & -5.1 & -168 & -1.02 & 0.306 & 0.87 \\
\hline Unmatched & 0.06209 & 0.14582 & -25.3 & & -4.94 & 0 & $0.14^{* *}$ \\
\hline Matched & 0.06347 & 0.06841 & -1.5 & 94.1 & -0.57 & 0.566 & $1.32^{*}$ \\
\hline Unmatched & 0.83149 & 0.59072 & 55.1 & & 11.37 & 0 & $0.49^{* *}$ \\
\hline Matched & 0.82267 & 0.81105 & 2.7 & 95.2 & 0.56 & 0.577 & 0.91 \\
\hline
\end{tabular}




\begin{tabular}{|c|c|c|c|c|c|c|c|c|}
\hline \multirow[t]{2}{*}{ Kalimantan Timur } & Unmatched & 0.03867 & 0.18552 & -47.8 & & -9.49 & 0 & $0.30^{* *}$ \\
\hline & Matched & 0.0407 & 0.03924 & 0.5 & 99 & 0.14 & 0.891 & 1.04 \\
\hline \multirow[t]{2}{*}{ Sulawesi Tenggara } & Unmatched & 0.14641 & 0.16599 & -5.4 & & -1.14 & 0.253 & 0.9 \\
\hline & Matched & 0.15262 & 0.1314 & 5.8 & -8.4 & 1.13 & 0.26 & 1.14 \\
\hline \multirow[t]{2}{*}{ Maluku } & Unmatched & 0.12845 & 0.17331 & -12.6 & & -2.64 & 0.008 & $0.75^{*}$ \\
\hline & Matched & 0.13517 & 0.11424 & 5.9 & 53.3 & 1.17 & 0.24 & 1.12 \\
\hline \multirow[t]{2}{*}{ Maluku Utara } & Unmatched & 0.06906 & 0.1546 & -27.4 & & -5.6 & 0 & $0.44^{* *}$ \\
\hline & Matched & 0.07267 & 0.06831 & 1.4 & 94.9 & 0.32 & 0.752 & 1.08 \\
\hline \multirow[t]{2}{*}{ Papua Barat } & Unmatched & 0.16575 & 0.11229 & 15.5 & & 3.38 & 0.001 & $1.43^{*}$ \\
\hline & Matched & 0.17151 & 0.19157 & -5.8 & 62.5 & -0.96 & 0.335 & 0.91 \\
\hline \multirow[t]{2}{*}{ Papua } & Unmatched & 0.16851 & 0.12205 & 13.2 & & 2.87 & 0.004 & $1.30^{*}$ \\
\hline & Matched & 0.17151 & 0.1561 & 4.4 & 66.8 & 0.77 & 0.44 & 1.07 \\
\hline
\end{tabular}

Source: Author's estimation based on IFLS-East 2012 